\title{
Oral subchronic toxicity of (+)-2,2'- epicytoskyrin a on male mice (Mus musculus)
}

\author{
Ni Luh Putu Rischa Phadmacanty ${ }^{1}$, Dewi Wulansari ${ }^{2}$ Andria Agusta $^{2}$, Sitarina Widyarini ${ }^{3}$, \\ and Kurniasih ${ }^{3}$ \\ ${ }^{1}$ Museum Zoologicum Bogoriense, Research Center for Biology, Indonesian Institute of Sciences, \\ Bogor, Indonesia \\ ${ }^{2}$ Department of Botany, Research Center for Biology, Indonesian Institute of Sciences, Bogor, \\ Indonesia \\ ${ }^{3}$ Faculty of Veterinary Medicine, Gadjah Mada University, Yogyakarta, Indonesia.
}

\begin{abstract}
Epicytoskyrin A (EpiA) is a secondary metabolite derived from an endophytic fungus Diaporthe sp. associated with the Gambier plant. EpiA has been reported to possess anticancer, antifungal, and antibacterial activities. In a mouse model, EpiA was also shown to low oral toxicity. Until now, there is no negative effect of EpiA reported yet. This study aimed to study the subchronic toxicity of this component in mice. This study used 60 male mice (Mus musculus) which were divided into four groups of treatments. Parameters that were analyzed were body weight, food consumption, blood chemicals, and histology. The results showed no significant difference in body weight gain and food consumption in all groups. Blood chemicals analysis showed increasing AST and ALT in dosage $12.5 \mathrm{mg} / \mathrm{kg} \mathrm{BW}$ groups at day 90 . Histological changes showed fatty degeneration and hydropic degeneration in the liver and mild inflammation in the kidney. No irreversible toxic effect of this component. So it can be beneficial for plant-based drug discovery. On the other hand, this study provides information about the safety of the development of EpiA as a drug candidate.
\end{abstract}

\section{Introduction}

(+)-2,2'- Epicytoskyrin A (EpiA) is a secondary metabolite produced by Diaporthe sp. associated with the gambier plant Uncaria gambir. This compound is first isolated from the tea plant (Camelia sinensis) with the molecule formula $\mathrm{C}_{30} \mathrm{H}_{23} \mathrm{O}_{12}$. This compound has a similar physiochemical with another bisantraquinone cytoskyrin A [1]. Recent data about EpiA showed that this compound has a cytotoxic effect with MIC value $<16 \mu \mathrm{g} / \mathrm{ml}$ for KB cells (mouth cancer), HELA cells (cervical cancer), MCMB2 cells (breast cancer), K5G2 cells (leukemia), and A549 cells (lung cancer) in vitro. This metabolite also gave an antimicrobial effect for Staphylococcus aureus and Candida tropicalis with MIC value $<16$ $\mu \mathrm{g} / \mathrm{ml}$ [2]. EpiA was effective in decreasing liver inflammation because of Staphylococcus aureus infection in mice [3]. In the previous study, we observe the acute toxicity of EpiA in

\footnotetext{
* Corresponding author: kurniasih_1951@yahoo.co.id
} 
mice was moderately toxic with $\mathrm{LD}_{50}$ of $1638,87 \mathrm{mg} / \mathrm{kg} \mathrm{BW}$ [4]. For the next step development of EpiA as a drug candidate, the subchronic toxicity test will be discussed in this paper.

\section{Materials and Methods}

\subsection{Chemical}

EpiA was prepared from the culture of the endophytic fungi Diaporthe sp. GNBP-10 as reported previously [1]. Diaporthe sp. GNBP-10 was cultivated on Potato Dextrose Broth (PDB) $(25 \times 200 \mathrm{~mL})$ medium and then extracted with ethyl acetate three times and dried under reduced pressure. The crude extract $(1.21 \mathrm{~g})$ was separated through Sephadex LH-20 (300 mL, Amersham Biosciences) column chromatography and eluted with methanol [5]. (+)-2,2'-Epicytoskyrin A appeared as fraction $1(\mathrm{~F} 1,0.219 \mathrm{~g})$ and was further purified by precipitation in $60 \%$ methanol in the water at room temperature. Its purity was determined by a reversed-phase HPLC analysis equipped with a Capcell-Pak C18 column (Shiseido) and run with an isocratic solvent system of $55 \%$ of acetonitrile in $40{ }^{\circ} \mathrm{C}$ for $30 \mathrm{~min}$ at a flow rate of $1 \mathrm{~mL} / \mathrm{min}$ and wavelength of $254 \mathrm{~nm}$. Determination of the chemical structure of EpiA was deduced base on their ${ }^{1} \mathrm{H}-\mathrm{NMR}(500 \mathrm{MHz})$ and ${ }^{13} \mathrm{C}-\mathrm{NMR}(125 \mathrm{MHz})$ data (JEOL ECA500, DMSO-d ) and compared with published data of EpiA previously isolated from Diaporthe sp. [4].

\subsection{Animals and Diets}

Sixty male DDY mice (6 weeks old; weight 20-25 g) were obtained from the National Veterinary Drug Assay Laboratory Bogor Indonesia (BBPMSOH) Gunung Sindur Bogor. Mice were acclimated for a week before treatment. The animals' room was maintained by 12 light/dark cycles. Animals caged by groups in transparent cages and stainless steel wire on top. The basal diet pellet was purchase from BBPMSOH Gunung Sindur and drinks using tap water. Food and water were given by ad libitum during the acclimatization and treatment.

\subsection{Ethical Clearance}

The treatment and observation were approved by the ethics committee of The Integrated Research and Testing Laboratory (LPPT) Gadjah Mada University, with ethical clearance number 118/KEC-LPPT/IX/2013.

\subsection{Treatment Group}

Sixty male mice were group into four treatments consisting of 15 animals. The groups were treated by $1 \% \mathrm{CMC} \mathrm{Na}$ (control), EpiA dosage $6,25 \mathrm{mg} / \mathrm{kg} \mathrm{BB}$ in $1 \% \mathrm{CMC} \mathrm{Na}(\mathrm{P} 1)$, EpiA dosage $12,5 \mathrm{mg} / \mathrm{kg} \mathrm{BB}$ in $1 \% \mathrm{CMC}(\mathrm{P} 2)$, and EpiA in $1 \% \mathrm{CMC} \mathrm{Na} \mathrm{(P3).} \mathrm{Bodyweight} \mathrm{and}$ food consumption were recorded daily throughout the treatment. Five animals from each group were sacrificed on days $0,45^{\text {th }}$, and $90^{\text {th }}$ by ether overdose. Subsequently, blood, liver, and kidney samples were collected by histopathological examination using Hematoxylin Eosin Staining. 


\subsection{Blood chemical analysis}

The blood samples were centrifuged by Eppendorf centrifuge 5424 at $1000 \mathrm{rpm}$ for 10 minutes. Serum was analyzed at Primate Research Center (PSSP) IPB University for blood chemical analysis.

\subsection{Statistical analysis}

The means and standard deviation were calculated by measure the data in each group, including feed consumption, body weight, and clinical-pathological data. The data compared by factorial pattern analysis, and the histopathological data analyzed qualitatively.

\section{Results}

The bodyweight of the animals was measured daily from day-0 to day-90. During 90 days of study, the observation showed no death or changes in behavior and physical appearances in all groups. Increasing the body weight gain was shown in all treatment groups. The lowest value of body weight was in the P3 group, and the highest value was in the control group (Fig 1), but there were no significant differences in mean body weight gain. Food consumption of the treatment showed no significant differences. Control and P1 groups showed an increase in food consumption in the first three weeks and then decrease until the sixth weeks and stable until the last treatment. Other treatments (P2 and P3) showed food consumption decrease from the first weeks until the sixth weeks and then being stable until the last treatment (Fig 2).

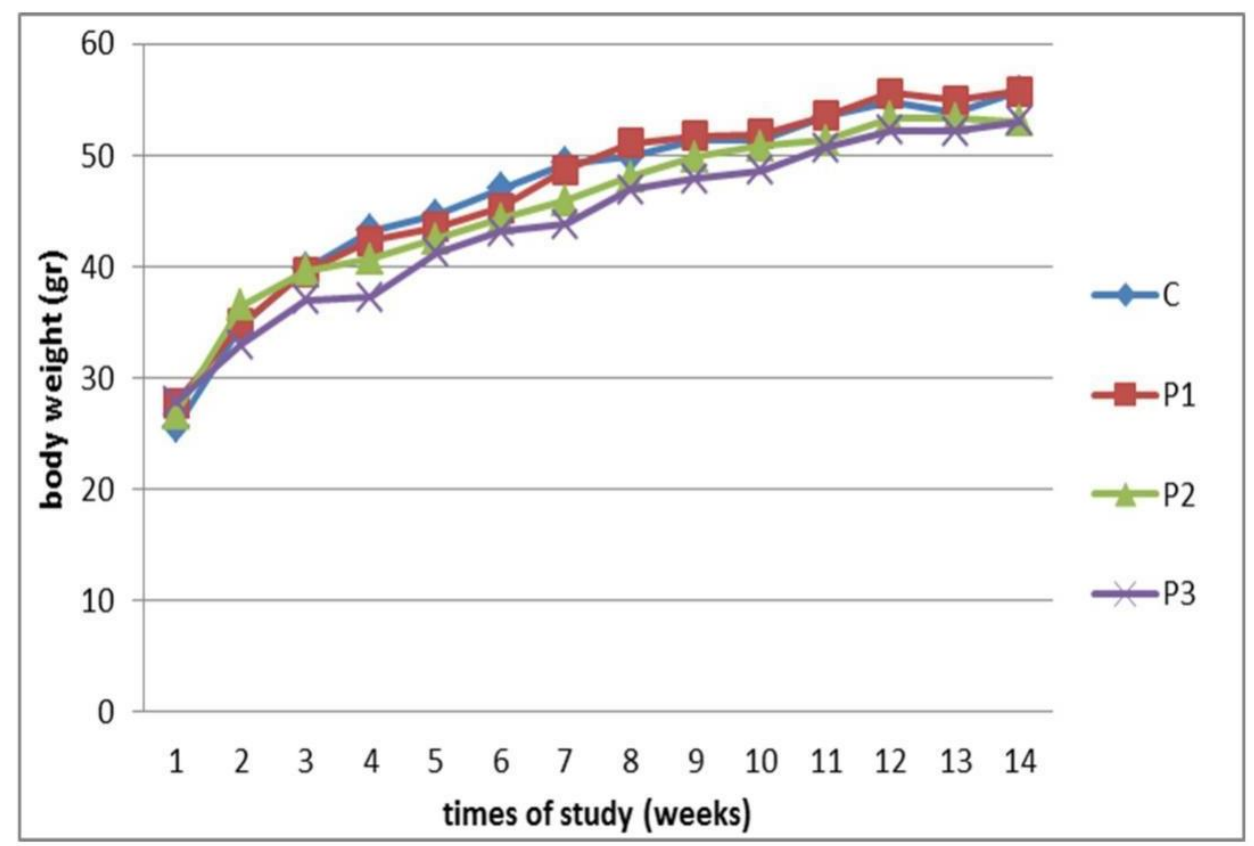

Fig 1. Growth curve of mice administrated by of 2,2'-Epicytoskyrin A (C. control; P1. 2,2'Epicytoskyrin A 6,25 mg/kg BW; P2. 2,2'-Epicytoskyrin A 12,5 mg/kg BW, P3. 2,2'-Epicytoskyrin A $25 \mathrm{mg} / \mathrm{kg} \mathrm{BW}$ ). 


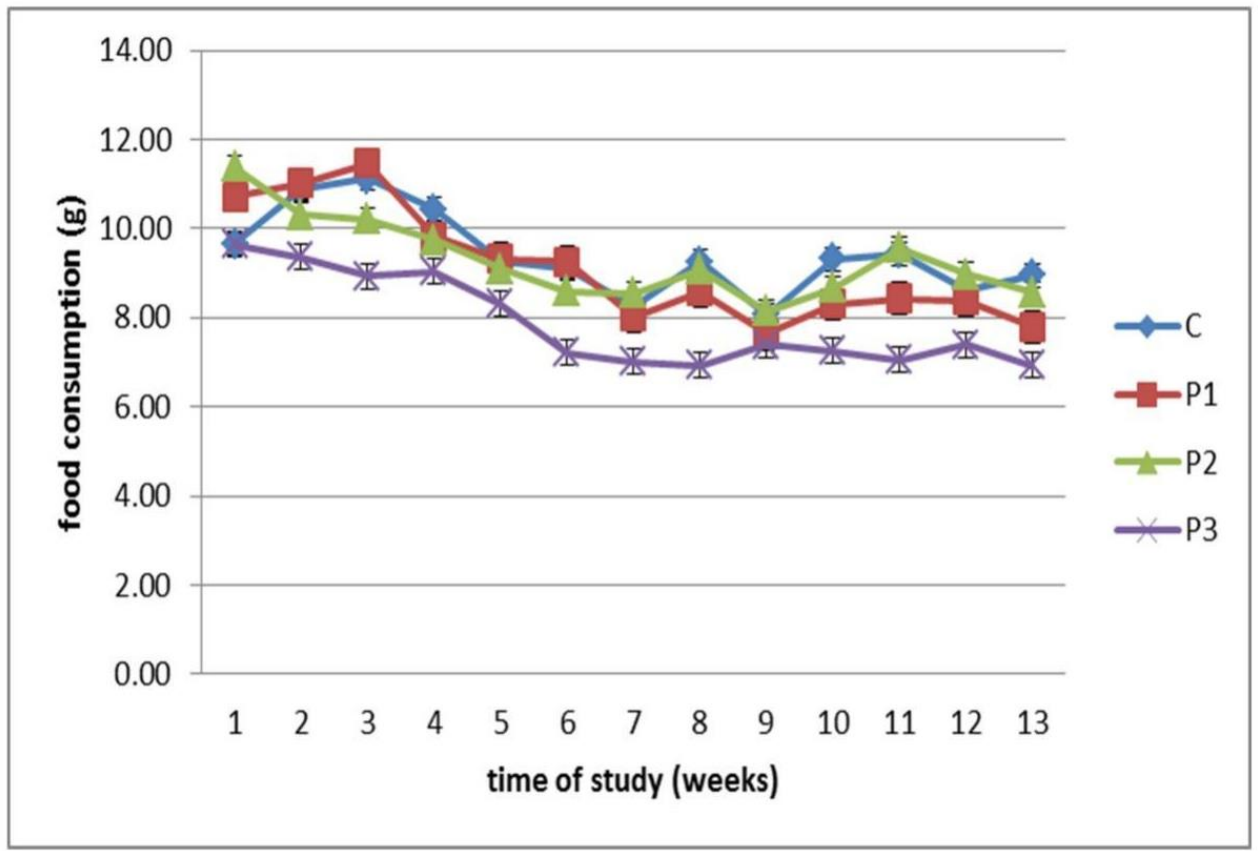

Fig 2. Food consumption curve of mice by 2,2'-Epicytoskyrin A. K. control; P1. 2,2'-Epicytoskyrin A $6,25 \mathrm{mg} / \mathrm{kg} \mathrm{BW}$; P2. 2,2'-Epicytoskyrin A $12,5 \mathrm{mg} / \mathrm{kg}$ BW, P3. 2,2'-Epicytoskyrin A $25 \mathrm{mg} / \mathrm{kg} \mathrm{BW}$

Blood chemical analysis showed that almost all blood parameters showed the normal condition except the AST and ALT level on day 90 (Table 1). Histological changes of the organs were occurred in all groups except the control group for liver and dose $12,5 \mathrm{mg} / \mathrm{kg}$ BW group for the kidney. There was hydropic and fatty degeneration in the livers and inflammation in the kidneys (Table 2, Fig 3). 
Table 1. Blood Chemical Analysis

\begin{tabular}{|c|c|c|c|c|c|}
\hline Control & & Control & $\begin{array}{l}\text { P1 (6,25 } \\
\mathrm{mg} / \mathrm{kg} \mathrm{BW})\end{array}$ & $\begin{array}{l}\text { P2 }(12,5 \\
\mathrm{mg} / \mathrm{kg} \mathrm{BW})\end{array}$ & $\begin{array}{l}\text { P3 (25 mg/kg } \\
\text { BW) }\end{array}$ \\
\hline \multirow{3}{*}{$\begin{array}{l}\text { ALT } \\
(\mathrm{IU} / \mathrm{L})\end{array}$} & Day 0 & $109 \pm 35.86$ & $112.16 \pm 37.70$ & $112.54 \pm 37$ & $122 \pm 50.95$ \\
\hline & Day 45 & $\begin{array}{l}121.76 \pm 25.2 \\
6\end{array}$ & $122.06 \pm 21.87$ & $149.3 \pm 21.56$ & $138.28 \pm 21.65$ \\
\hline & Day 90 & $\begin{array}{l}140.68 \pm 35.1 \\
4\end{array}$ & $142.42 \pm 36.28$ & $227.18 \pm 36.78$ & $174.44 \pm 37.07$ \\
\hline \multirow{3}{*}{ AST (UI/L) } & Day 0 & $51.56 \pm 12.39$ & $41.04 \pm 5.03$ & $56.32 \pm 24.37$ & $46.54 \pm 10.86$ \\
\hline & Day 45 & $72.82 \pm 8.84$ & $63.7 \pm 9.24$ & $76.38 \pm 33.45$ & $79.92 \pm 38.51$ \\
\hline & Day 90 & $74.54 \pm 9.44$ & $72.6 \pm 9.02$ & $\begin{array}{l}178.88 \pm 226.4 \\
6\end{array}$ & $75.64 \pm 20.50$ \\
\hline \multirow{3}{*}{$\begin{array}{l}\text { BUN } \\
(\mathrm{mg} / \mathrm{dL})\end{array}$} & Day 0 & $24.76 \pm 5.33$ & $30.78 \pm 10.99$ & $34.4 \pm 13.56$ & $20.1 \pm 5.38$ \\
\hline & Day 45 & $24.12 \pm 4.8$ & $29 \pm 5.63$ & $25.94 \pm 5.88$ & $25.98 \pm 5.98$ \\
\hline & Day 90 & $17.22 \pm 3.76$ & $16.56 \pm 3.64$ & $16.42 \pm 2.86$ & $15.34 \pm 1.97$ \\
\hline \multirow{3}{*}{$\begin{array}{l}\text { Creatinine } \\
(\mathrm{mg} / \mathrm{dL})\end{array}$} & Day 0 & $0.37 \pm 0.089$ & $0.438 \pm 0.04$ & $0.478 \pm 0.1$ & $0.396 \pm 0.119$ \\
\hline & Day 45 & $0.584 \pm 0.085$ & $0.586 \pm 0.084$ & $0.518 \pm 0.063$ & $0.105 \pm 0.104$ \\
\hline & Day 90 & $\begin{array}{l}0.546 \pm 0.097 \\
8\end{array}$ & $0.542 \pm 0.111$ & $0.542 \pm 0.076$ & $0.63 \pm 0.100$ \\
\hline
\end{tabular}

Table 2. Percentages of each group that showed kidney and liver changes at day 90

\begin{tabular}{|c|c|c|c|}
\hline \multirow[t]{2}{*}{ Group } & \multirow[t]{2}{*}{ Histological changes } & \multicolumn{2}{|c|}{$\%$ individuals } \\
\hline & & Liver & Kidney \\
\hline \multirow[t]{4}{*}{ Control (K) } & Hydropic degeneration & $0 \%$ & $0 \%$ \\
\hline & Fatty degeneration & $0 \%$ & $0 \%$ \\
\hline & Necrotic & $0 \%$ & $0 \%$ \\
\hline & Inflammation & $0 \%$ & $80 \%$ \\
\hline \multirow{4}{*}{$\begin{array}{l}\text { (+)-2,2'-Epicytoskyrin A } \\
\text { dosage } 6,25 \mathrm{mg} / \mathrm{kg} \mathrm{BW} \\
\text { (P1) }\end{array}$} & Hydropic degeneration & $20 \%$ & $0 \%$ \\
\hline & Fatty degeneration & $0 \%$ & $0 \%$ \\
\hline & Necrotic & $0 \%$ & $0 \%$ \\
\hline & Inflammation & $0 \%$ & $60 \%$ \\
\hline \multirow{4}{*}{$\begin{array}{l}\text { (+)-2,2'-Epicytoskyrin A } \\
\text { dosage } 12,5 \mathrm{mg} / \mathrm{kg} \mathrm{BW} \\
\text { (P2) }\end{array}$} & Hydropic degeneration & $0 \%$ & $0 \%$ \\
\hline & Fatty degeneration & $40 \%$ & $0 \%$ \\
\hline & Necrotic & $0 \%$ & $0 \%$ \\
\hline & Inflammation & $0 \%$ & $0 \%$ \\
\hline \multirow{4}{*}{$\begin{array}{l}\text { (+)-2,2'-Epicytoskyrin A } \\
\text { dosages } 25 \mathrm{mg} / \mathrm{kg} \mathrm{BW} \\
\text { (P3) }\end{array}$} & Hydropic degeneration & $60 \%$ & $0 \%$ \\
\hline & Fatty degeneration & $0 \%$ & $0 \%$ \\
\hline & Necrotic & $0 \%$ & $0 \%$ \\
\hline & Inflammation & $0 \%$ & $80 \%$ \\
\hline
\end{tabular}




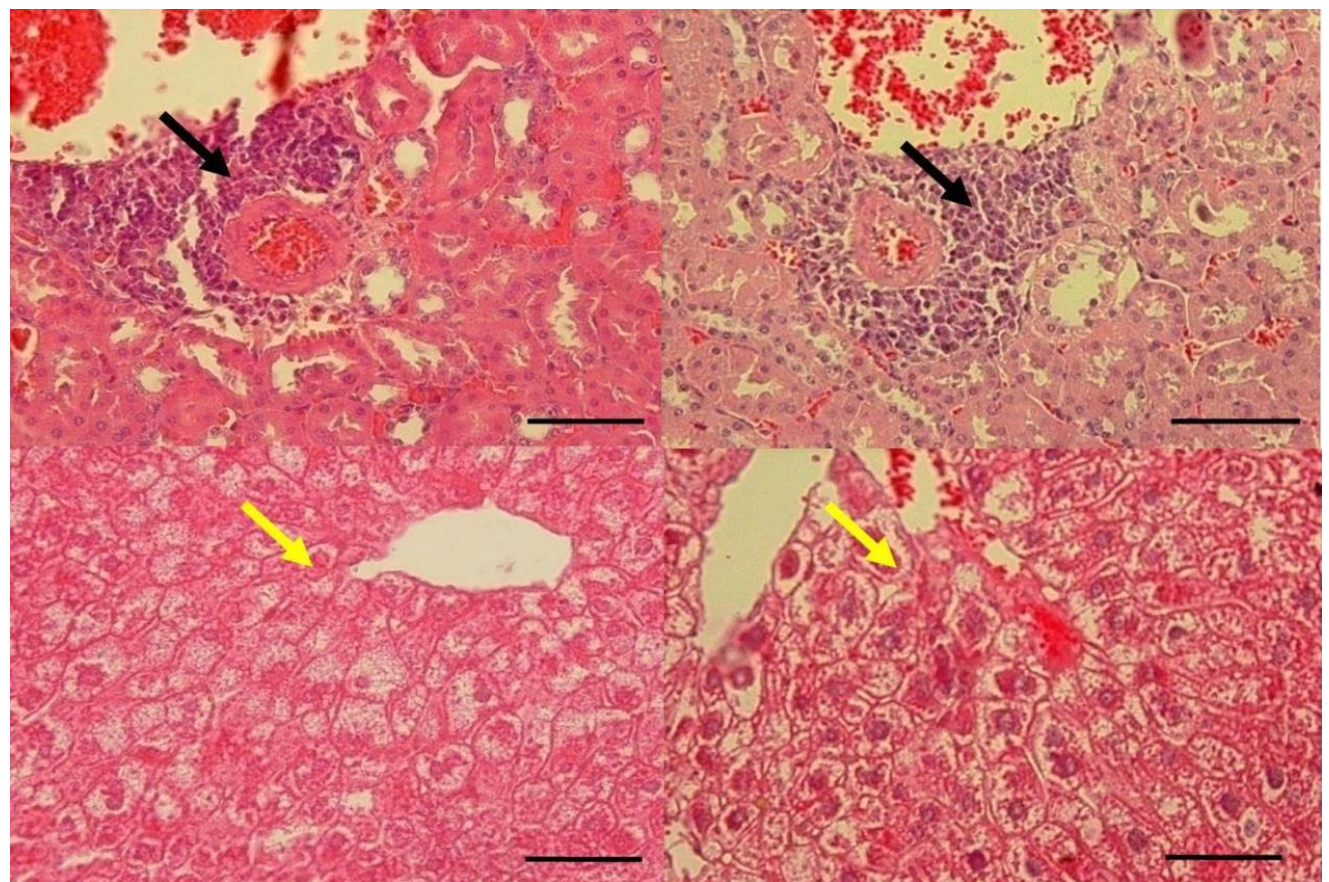

Fig 3. Kidney and liver histology at day $90^{\text {th }}$ (A. nephritis in the control group, B. nephritis in the group given (+)-2,-2'-Epicytoskyrin A doses $25 \mathrm{mg} / \mathrm{kg} \mathrm{BB}$ ), C. Liver hydropic degeneration in the group given (+)-2,-2'-Epicytoskyrin A dosage $6,25 \mathrm{mg} / \mathrm{kg}$ BB D. Liver hydropic degeneration in the group given (+)-2,-2'-Epicytoskyrin A doses $25 \mathrm{mg} / \mathrm{kg}$ BB. (scale bar $50 \mu \mathrm{m}$; black arrows: inflammation; yellow arrows: hydropic degeneration)

\section{Discussion}

The results indicated that EpiA has no effect on body weight in all treatment groups. The increase of body weight in the first six weeks was normal because some laboratory mice strains have high weight gain in the first four weeks, then the body weight became stable [6]. The levels of BUN and creatinine showed the kidney functions of animals. Increasing BUN and creatinine levels indicated a lack of filtration rate in the glomerulus $[7,8]$. The result showed that all groups have normals blood chemical values for kidney function. There were 19-34 mg/dL for the normal BUN, and 0,5-0,8 mg/dL for the normal creatinine [9]. Although in a normal condition, the value of BUN decreased throughout the time of treatment. This case could cause by liver failure that influences the urea production of the liver cell. Besides that, decreasing of food consumption of the mice also influenced BUN value in the blood [10].

The value of creatinine in this research showed elevation during treatment but within the normal range. Some antibiotics induced increasing the creatinine value, the examples gentamicin [11], cephalosporin, and vancomycin [12,13]. They also caused kidney failures such as acute interstitial nephritis and glomerulonephritis. The histology figures of this research showed the inflammation in almost all treatment groups. Just treatment with dosage $12,5 \mathrm{mg} / \mathrm{kg} \mathrm{BW}$ that has the normal condition (Table 1). Many factors that cause inflammation and drug is one of them. Inflammation caused by a drug commonly occurred accompanied by proteinuria [14], but this research showed interstitial nephritis. Interstitial nephritis usually occurred because of allergies. Interstitial nephritis in this research was 
present in the control group while the treatment EpiA dose of $12.5 \mathrm{mg} / \mathrm{kg}$ group did not present, so maybe it was not because of EpiA.

Histopathological features in this study were mostly reversible degeneration that released little amount of enzyme aminotransferase. In the dose of $12.5 \mathrm{mg} / \mathrm{kg}$ group on day 90 , they indicated a severe fatty degeneration that causes the release of the high amount of the enzyme aminotransferase. Fatty degeneration is one characteristic that the toxic effect of the chemical component [15]. This degeneration occurs only in treatment with a dose of $12.5 \mathrm{mg} / \mathrm{kg}$, while treatment of $25 \mathrm{mg} / \mathrm{kg}$ on the 90th day showed hydropic degeneration that is an early stage of injury. Base on the results, a high concentration of EpiA will decrease its solubility in water. Hence the absorption of this component in the digestive system will be slower and influences the toxicity effect [16].

The mechanism of action of EpiA is not yet well established. The current report about EpiA explained that this component could cause oxidative stress in yeast [17]. The oxidative stress increased flexibility and the diffusibility of membranes. It caused the leak out of the liver enzyme from the cells $[18,19,20]$. Alanine aminotransferase (ALT) and aspartate aminotransferase (AST) were enzymes produced by liver damage cells. ALT and AST levels in the blood showed liver function in the animals. Blood chemical for liver function (AST and ALT) showed normal conditions except treatment for EpiA dose of $12.5 \mathrm{mg} / \mathrm{kg}$ day 90 (P2) that indicated increased levels of AST and ALT levels in the last treatment (Table 1). The increase of AST levels in the blood indicated some problems in the liver. AST is a mitochondrial enzyme released by liver cell damage [10]. Increased levels of AST and ALT showed that EpiA had effects on liver functions.

Other anthraquinones with a chemical structure close to EpiA, were rugulosin and luteoskyrin. Rugulosin had a cytotoxic activity for Escherichia coli, Tetrahymena pyriformis, Ehrlich tumor cells, and culture mammal cells. Rugulosin had LD L $_{50} 4000 \mathrm{mg} / \mathrm{kg} \mathrm{BW}$ for mice by peroral administration. Subchronic toxicity of this component that was given by rugulosin 1,5 g/ mouse/day for 22 days showed several tissue injuries such as liver fatty degeneration, liver necrosis, nuclear damage of liver cells, and nephrotic in the kidney [21]. Another compound, luteoskyrin, had $6,55 \mathrm{mg} / \mathrm{kg} \mathrm{BW}$ of $\mathrm{LD}_{50}$, and it also harms the liver. There were necrosis, hepatoma, leukemia and increasing of serum transaminase founded in mice treated by that compound $[22,23]$. Compared with EpiA, there were rugulosin and luteoskyrin more toxic than EpiA. Both Rugulosin and Luteoskyrin had several toxicity effects for tissue, with $\mathrm{LD}^{50}$ value were lower than EpiA. The common antibiotics that widely use for veterinary medicine were Erythromycin and Chloramphenicol. Erythromycin had an $\mathrm{LD}_{50}$ value of more than $300 \mathrm{mg} / \mathrm{kg}$ bb for mice, rats, guinea pigs, hamsters, rabbits, and dogs [24], and both of them had toxicity effects on the liver $[25,26]$ but limited data about the nephrotoxicity effect. Although several antibiotics had toxicity effects, we always needed drugs in treatment. The use of antibiotics will be safe if consumed by the correct dosage and timing of use.

\section{Conclusion}

Based on this research, it is concluded EpiA has a mild toxic effect on the liver. The histological changes in all treatments showed reversible toxicity effects that get better after stopping the exposure to EpiA. The value of ALT and AST also showed that this component has a mild effect. This result can be beneficial for microbial derive drug discovery and provides information about the safety of EpiA as a drug candidate.

We are thankful to the Ministry of Research, Technology, and Higher Education (KEMENRISTEKDIKTI) for a scholarship awarded to NLPRP and Kompetitif research grant Indonesian Institute of Sciences (LIPI) awarded to AA, which funded this research. The authors declare that they have no competing interests and the first author is the main contributor of this article. 


\section{References}

1. A. Agusta, K. Ohashi, H. Shibuya, Chem. Pharm. Bull. 54, 579-582 (2006)

2. A. Agusta, D. Wulansari, Y. Jamal, A. Nurkanto, Praptiwi, A. Fathoni. Microbiol Indones. 9, 1, 35-43 (2015)

3. N.L.P.R. Phadmacanty, D. Wulansari, K.D. Palupi, A. Agusta, Zoo Indones. 25, 2, 8389 (2016)

4. Praptiwi, A. Nurkanto, D. Wulansari, A. Agusta, Ber. Biol. 14, 1, 11-18 (2015)

5. Praptiwi, Y. Jamal, A. Fathoni, A. Nurkanto, A. Agusta, Microbiol. Indones. 7, 4, 159166 (2013)

6. G.A.E. Gall, W.H. Kyle, Theor. Appl. Genet. 38, 304-308 (1968)

7. D. Thomas, S. Zachariah, A.E.E. Elamin, H.A.L. Osman, Sch. Acad. J. Pharm. 6, 5, 168170 (2017)

8. K. Azra, Indian J. Fundam. Appl. Life. Sci. 4, 4, 199-202 (2014)

9. M.A. Suckow, P. Danneman, C. Brayton, The Laboratory Mouse (CRC Press, New York, 2001)

10. M.D. Willard, D.C. Twedt. Gastrointestinal, pancreatic, and hepatic disorders, in: Small Animal Clinical Diagnosis by Laboratory Methods (Elsevier Inc, 2012)

11. P. Balakumar, A. Rohilla, A. Thangathirupathi, Pharmacol. Res. 62, 179-186 (2010)

12. V. Fanos, L. Cataldi, J. Chemother. 13, 5, 461-472 (2001)

13. E.L. Cano, N.Z. Haque, V. L. Welch, et al. Clin. Ther. 34, 1, 149-157 (2012)

14. E. Bae, T.W. Lee, D.J. Park, J. Korean Med. Assoc. 63, 1, 30-35 (2020)

15. J.F. Hardisty, A.E. Brix. Toxicol. Pathol. 33, 1, 35-40 (2005)

16. K.T. Savjani, A.K. Gajjar, J.K. Savjani, ISRN Pharm. 2012, 1-10 (2012)

17. D. Wulansari, P. Praptiwi, H. Julistiono, A. Nurkanto, A. Agusta, Makara J. Sci. 20, 4, 160-166 (2016)

18. D.E. Amacher. Regul. Toxicol. Pharmacol. 27, 2, 119-130 (1998)

19. H. Jaeschke, J. Gastroenterol. Hepatol. 26, 173-179 (2011)

20. I.G. Kirkinezos, C.T. Moraes, Semin Cell Dev. Biol. 12, 6, 449-457 (2001)

21. Y. Ueno, N. Sato, T. Ito, I. Ueno, M. Enomoto, H. Tsunoda, J. Toxicol. Sci. 5, 295-302 (1980)

22. K. Uraguchi, M. Saito, Y. Noguchi, K. Takahashi, M. Enomoto, T. Tatsuno, Food Cosmet. Toxicol. 10, 2, 193-207(1972)

23. I. Ueno, T. Horiuchi, M. Enomoto. Toxicol. Appl. Pharmacol. 52, 2, 278-284 (1980)

24. EMEA. Committee for Veterinary Medicinal Products Erythromycin Summary Report (2). (London, 2000)

25. A.B. Saba, O. Ola-Davies, M. Oyeyemi, O. Ajala, African J. Biomed Reseach. 3, 133137 (2000)

26. E.H. Kaltiala, O. Räsänen, E. Herva, N.T. Kärki. Acta Pharmacol. Toxicol. (Copenh). 25, 435-446 (1967) 